\title{
Eosinophils and childhood asthma
}

Bong Seok Choi, MD

Department of Pediatrics, School of Medicine, Kyungpook National University, Daegu, Korea

Eosinophils are a type of granulocyte with eosinophilic granules in the cytoplasm that play an important role in allergic and parasitic diseases. Eosinophils are important in the pathogenesis of asthma, and many studies have examined the relationship between them. In allergic eosinophilic asthma, eosinophils act not only as important effector cells but also as antigen-presenting cells in allergic inflammatory reactions. In nonallergic eosinophilic asthma, type 2 innate lymphoid cells in the airways play an important role in eosinophil activation. Direct methods, including bronchial biopsy, bronchoalveolar lavage, and the induced sputum test, are used to evaluate eosinophilic inflammatory reactions in patients with asthma, however, because of difficulty with their implementation, they are sometimes replaced by measurements of blood eosinophils, fraction of exhaled nitric oxide, and serum periostin level. However, these tests are less accurate than direct methods. For the treatment of patients with severe eosinophilic asthma, anti-interleukin-5 preparations such as mepolizumab, reslizumab, and benralizumab have recently been introduced and broadened the scope of asthma treatment. Although eosinophils are already known to play an important role in asthma, we expect that further studies will reveal more details of their action.

Key words: Anti-IL-5, Asthma, Child, Eosinophil, Pathogenesis

\section{Key message}

- In allergic eosinophilic asthma, eosinophils act as important effector cells and antigen-presenting cells, while in nonallergic eosinophilic asthma, type 2 innate lymphoid cells play an important role in eosinophil activation.

- Sputum eosinophil counts can be helpful for evaluating allergic airway inflammation in asthma.

- Anti-interleukin-5 has broadened the scope of asthma treatment.

\section{Introduction}

Asthma is a chronic inflammatory disease of the airways associated with reversible airway obstruction, bronchial hypersensitivity, and varying degrees of symptoms. ${ }^{1}$ About 300 million people worldwide have asthma, with an estimated 2 million in Korea. ${ }^{2,3)}$ The different asthma subtypes result from the complex interaction among several genetic and environmental factors and present as multiple phenotypes. ${ }^{4)}$ In the pathogenesis of asthma, T cells, especially $\mathrm{T}$ helper 2 (Th2) cells, play an important role in the initiation and maintenance of inflammation. Recent studies suggest that there are at least 2 endotypes of asthma, T2 "high" and T2 "low" according to the extent of Th2-mediated inflammation. ${ }^{5,6}$ ) The exact role of eosinophils in asthma remains controversial. ${ }^{7-10)}$ Eosinophilia does not increase in all cases of asthma; it is more common in allergic asthma but may also increase in nonallergic asthma. ${ }^{11)}$ The recent use of eosinophil-related anti-interleukin (IL) 5 agents in clinical practice may require further understanding of the role of eosinophils in asthma and help elucidate the role of eosinophils. This review discusses the relationship between asthma and eosinophils.

\section{Eosinophils}

Eosinophils, a type of granulocyte with eosinophilic granules in the cytoplasm, account for 1\%-3\% of white blood cells in the blood of healthy people. They are slightly larger than red blood cells. ${ }^{12,13)}$ The level of eosinophils in the blood is highest in the morning and lowest in the afternoon. The nucleus is composed of 2 connected lobes, and the cytoplasm is filled with granules that stain red on hematoxylin and eosin staining. Eosinophils are produced in the bone marrow and circulate in the blood for approximately 18 hours, then migrate to the tissues and are present primarily in the tissues (>95\%). Tissue eosinophils are generally distributed in the gastrointestinal mucosa, particularly the small intestine, and some are found in the spleen and lymph nodes. Eosinophils are believed to survive for more than 8-12 days in the tissues, but data are limited. Eosinophils generally do not recirculate and are discharged or dissolved in the intestinal lumen. ${ }^{13)}$ Their granules can cause tissue damage or dysfunction. In addition, eosinophils secrete inflammatory cytokines, such

Corresponding author: Bong Seok Choi, MD. Department of Pediatrics, School of Medicine, Kyungpook National University, 130 Dongdeok-ro, Jung-gu, Daegu 41944, Korea 
as IL-2, IL-4, IL-5, IL-10, IL-12, IL-13, IL-16, IL-18, and transforming growth factor $\alpha / \beta$ (TGF- $\alpha / \beta)$; chemokines such as RANTES (regulated on activation, normal $\mathrm{T}$ cell expressed and secreted) and eotaxin 1; and lipid mediators such as platelet-activating factors and leukotriene C4. ${ }^{14)}$ Eosinophils are involved in the pathophysiology of various diseases, including parasitic and allergic diseases. ${ }^{15)}$ Eosinophils move from the blood to inflammatory sites, perform multiple functions by directly controlling cytokines and inflammatory responses, and act as antigen-presenting cells in inflammatory responses.

\section{Eosinophilic and noneosinophilic asthma}

Eosinophilic asthma (EA) features a significant number of eosinophils in the airway and/or blood, whereas non-EA (NEA) features a small number of eosinophils. ${ }^{16}$ EA is diagnosed on the induced sputum test when eosinophils comprise more than 2\%$3 \%$ of the total cells in a sample. ${ }^{17)}$ Inhaled corticosteroids are preferred to other drugs for treatment of EA. ${ }^{18,19)}$ In severe cases of EA that do not respond well to high-dose inhaled or systemic steroids, eosinophil-related biologics may be considered. EA can be divided into allergic and nonallergic EA. Allergic EA, also known as general EA, is associated with eosinophilia, part of the Th2 allergic inflammatory response, while nonallergic EA is caused by a mechanism other than allergic inflammation. The mechanisms are discussed in the next section, "pathogenesis of asthma and eosinophils."

In recent studies, asthma phenotypes were classified into several clusters rather than EA versus NEA. In the cluster analysis of the Severe Asthma Research Program cohort, the children were divided into 4 childhood asthma clusters (late-onset symp tomatic asthma, early-onset atopic asthma with normal lung function, early-onset atopic asthma with mild airflow limitation, and early-onset atopic asthma with advanced airflow limitation) according to asthma duration, baseline lung function, and number of controller drugs required. There were various levels of blood eosinophils in all 4 clusters but no significant intergroup differences. ${ }^{20)}$ In the cluster study of the Unbiased Biomarkers for the Prediction of Respiratory Disease Outcome Consortium cohort, asthma patients were divided into 4 clusters, 3 of which were associated with eosinophilia. ${ }^{21)}$

\section{Pathogenesis of asthma and eosinophils}

In allergic EA, eosinophils are important effector cells of allergic inflammatory reactions. Their activation results in the extracellular release of granular proteins such as eosinophil cationic protein (ECP), eosinophil-derived neurotoxin, major basic protein (MBP), and eosinophil peroxidase (EPO). ${ }^{22)}$ Among the various mediators secreted by eosinophils, these granules play the most powerful and important role in the pathophysiology of asthma. ${ }^{23}$ Eosinophils also release a number of cytokine, chemokine, and lipid mediators. In allergic inflammatory reactions, eosinophils have been considered terminal effector cells, but recent studies have shown that they are also involved in the early stages of the development of allergic diseases. ${ }^{24)}$ Eosinophils can act as antigen-presenting cells, inducing T-cell activation and cytokine production in early disease stages..$^{25,26}$

In nonallergic EA, type 2 innate lymphoid cells in the airways are thought to play an important role and be activated by IL-25, IL-33, and prostaglandin D2. ${ }^{27)}$ Type 2 innate lymphoid cells are a local source of IL-5 and IL-13, which are important for eosinophil activation and are associated with eosinophilia in the airways and the occurrence of severe asthma. ${ }^{28)}$

In connection with airway remodeling in asthma, activated eosinophils secrete several profibrogenic molecules. ECP increases proteoglycan production in fibroblast cell cultures, ${ }^{29)}$ increases TGF- $\beta$ production in fibroblasts, ${ }^{30)}$ and enhances collagen gel contraction. ${ }^{31)}$ Eosinophils also produce TGF- $\beta$, a powerful profibrogenic cytokine, on their own. EPO and MBP induce airway epithelial cells to produce TGFs, matrix metalloproteinases, and platelet-derived growth factors. ${ }^{32)}$ In one study, a decrease in eosinophils with anti-IL-5 administration decreased subepithelial fibrosis in the airways. ${ }^{33)}$

\section{Laboratory tests associated with eosinophils (eosinophil biomarkers) in asthma}

Methods for directly evaluating eosinophilic inflammation of the airways include bronchial biopsy, bronchoalveolar lavage, and the induced sputum test. Bronchial biopsy and bronchoalveolar lavage have been considered the gold standards for evaluating eosinophilic inflammation of the airways. ${ }^{34)}$ How. ever, because these tests are very invasive, the induced sputum test is the most widely used. ${ }^{35)}$

Sputum eosinophil counts decrease with corticosteroid treatment and are increased by allergen challenge. ${ }^{36}$ Monitoring sputum eosinophil counts showed reduced exacerbation numbers and severities in adult patients. ${ }^{37)}$ However, data are lacking for the same in children. Fleming et al. ${ }^{38)}$ reported that monitoring induced sputum in children did not significantly reduce overall exacerbations or improve asthma control. In this study, follow-up every 3 months revealed that exacerbations were reduced in the short term, suggesting that more frequent measurements would be needed to confirm a clinically useful effect.

There are some limitations to the induced sputum test. It is almost impossible to collect sputum from children under the age of 5 years, and the hypertonic saline used to induce sputum is likely to cause asthma attacks in asthmatic patients. In addition, the results of the sputum test are not immediately available after the samples have been obtained because skilled inspectors are required to examine the samples, which takes time. Accordingly, measurements of blood eosinophils, the fraction of exhaled nitric oxide (FeNO), and serum periostin level determination may be performed in the clinic instead of the induced sputum 
test to evaluate eosinophilic inflammation in the airways. ${ }^{39)}$

Blood eosinophil count can be easily performed at a lower cost than the induced sputum test. Despite a correlation between blood and sputum eosinophils, use of the former rather than latter has been controversial due to high false negative and positive rates. ${ }^{40)}$ Blood eosinophils are useful for screening patients with asthma who will respond well to biological agents such as anti-IL-5. . $^{\text {) }}$

FeNO is a gaseous molecule synthesized by nitric oxide synthase that is expressed in the airway epithelium and increases in the inflammatory state. Measuring FeNO is a noninvasive method for evaluating airway inflammation in asthma. The test is relatively simple and its results are immediately available. ${ }^{41}$ ) Many studies have shown a positive relationship between FeNO and sputum eosinophil count, ${ }^{42,43)}$ and FeNO has been proposed as a test for monitoring asthma. ${ }^{44)}$

Serum periostin is a recently introduced test that is used to indirectly evaluate eosinophilic airway inflammation in patients with asthma. In several reports, serum periostin levels were significantly correlated with sputum eosinophil counts. ${ }^{45,46)}$ Woodruff et al. ${ }^{47)}$ reported that the asthma group showed higher periostin gene expression in the bronchoalveolar lavage fluid and higher concentrations of IL-4, IL-5, and IL-13 than the control group as well as increased eosinophil concentrations in the bronchoalveolar lavage fluid. Wagener et al. ${ }^{48)}$ reported that serum periostin had lower accuracy than blood eosinophils and FeNO for evaluating eosinophilic inflammation in asthmatic patients.

Clinical studies on eosinophils and childhood asthma other than antieosinophil drugs summarized in Table 1.

\section{Antieosinophil (anti-IL-5) drugs and asthma}

IL-5 is a cytokine secreted by lymphocytes, mast cells, and eosinophils that is highly correlated with eosinophil differentiation, proliferation, and activation. ${ }^{49)}$ Thus, it is an important target in the consideration of biological treatment in EA patients. Anti-IL-5 therapy was introduced in the late 1990s based on animal studies that showed that airway hyperresponsiveness was suppressed and eosinophil counts in bronchoalveolar lavage fluid were reduced by anti-IL-5 therapy. ${ }^{50)}$ However, these findings did not demonstrate clinical success since pulmonary function improvement was the target. Anti-IL-5 therapy has attracted attention again from recent positive reports of its effectiveness with strengthened screening of target patients, and it is listed in asthma guidelines as a treatment for severe EA. Currently available anti-IL-5 agents include mepolizumab, reslizumab, and benralizumab (Table 2).

\section{Mepolizumab}

Mepolizumab (Nucala; GlaxoSmithKline, London, UK) is a humanized monoclonal antibody (IgG1) specific for IL-5 that has been approved by the U.S. Food and Drug Administration (FDA) for further treatment of patients aged 12 years or older with severe EA. Mepolizumab selectively inhibits eosinophilic inflammation and reduces the number of eosinophils in the sputum and blood. ${ }^{51)}$ In a randomized double-blind placebocontrolled study of 61 patients, mepolizumab reduced the frequency of exacerbations in patients with severe EA with repeated exacerbations despite the use of high-dose steroids $(P=0.02)$ and reduced eosinophil counts in the peripheral blood and sputum $(P<0.001)$ compared with the placebo group. ${ }^{52)}$ However, mepolizumab did not improve forced expiratory volume in 1 second $\left(\mathrm{FEV}_{1}\right)$ or airway hyperresponsiveness. In a small study, mepolizumab treatment reduced the use of systemic steroids in patients who had severe EA with uncontrolled symptoms despite the use of systemic steroids and high-dose inhaled steroids by $47.7 \%$ versus placebo $(P=0.04) .{ }^{51)}$ In the Steroid Reduction with Mepolizumab Study, mepolizumab reduced the steroid dose by 50\% in asthma patients with increased peripheral blood eosinophils and were receiving systemic steroids. In addition, the rate of acute exacerbation was 32\% lower $(P=0.04)$ and the Asthma Control Questionnaire (ACQ) score was also lower than that in the placebo group despite a significant reduction in steroid dose $(P=0.04)$. However, 3 months after treatment with mepolizumab was stopped, the eosinophilia in the blood and sputum returned to its original state. In the Mepolizumab as Adjunctive Therapy in Patients with Severe Asthma study, which included children aged 12 years or older in addition to adults, ${ }^{53)} 2$ doses of mepolizumab (75 mg intravenous, $100 \mathrm{mg}$ subcutaneous injection) were administered for 32 weeks at 4-week intervals to EA patients who had uncontrolled and repeated acute exacerbations despite the use of high-dose inhaled steroids. Acute exacerbations were reduced by $47 \%$ in the intravenous group and by $53 \%$ in the subcutaneous group compared with the placebo group $(P<0.001)$. Acute exacerbations requiring emergency visits or hospitalization decreased by $32 \%(P=0.03)$ in the intravenous group and by $61 \%(P=0.02)$ in the subcutaneous group. The intravenous and subcutaneous groups had improved ACQ scores compared with the placebo group $(P<0.001)$. The mean $\mathrm{FEV}_{1}$ increased by $100 \mathrm{~mL}(P=0.02)$ in the intravenous group and $98 \mathrm{~mL}(P=0.03)$ in the subcutaneous group versus the placebo group. In a study by Gupta et al., ${ }^{54)}$ children aged 6-11 years with severe asthma and blood eosinophil counts $\geq 150$ cells $/ \mathrm{mL}$ at screening or $\geq 300$ cells $/ \mathrm{mL}$ in the previous year were enrolled. They received subcutaneous mepolizumab (40 $\mathrm{mg},<40 \mathrm{~kg}$ ) or $100 \mathrm{mg}$ ( $\geq 40 \mathrm{~kg}$ ) over 52 weeks. Compared to baseline, mepolizumab treatment reduced blood eosinophil counts and asthma exacerbations and improved asthma control. Twenty-seven percent of patients experienced adverse events related to mepolizumab treatment, including headache, upper abdominal pain, and pyrexia, although the majority were moderate in intensity. 


\begin{tabular}{|c|c|c|c|c|}
\hline Source & Theme & Methods & Main results & Conclusion \\
\hline $\begin{array}{l}\text { Ross } \\
\text { et al. }\end{array}$ & $\begin{array}{l}\text { Prognosis of se- } \\
\text { vere asthma }\end{array}$ & $\begin{array}{l}\text { Children with severe asthma } \\
\text { were assessed annually for } 3 \\
\text { years. }\end{array}$ & $\begin{array}{l}\text { At baseline, } 111 \text { children ( } 59 \%) \text { had severe asthma. } \\
\text { After } 3 \text { years, only } 30 \% \text { of subjects met the criteria for } \\
\text { severe asthma. } \\
\text { The odds ratio in favor of resolution of severe asthma was } \\
2.75(95 \% \mathrm{Cl}, 1.02-7.43) \text { for those with a peripheral } \\
\text { eosinophil count of greater than } 436 \text { cells } / \mathrm{mL} \text {. }\end{array}$ & $\begin{array}{l}\text { Half of the children with severe as- } \\
\text { thma no longer had severe asth- } \\
\text { ma after } 3 \text { years. } \\
\text { Peripheral eosinophilia predicted } \\
\text { resolution. }\end{array}$ \\
\hline $\begin{array}{l}\text { Teague } \\
\text { et al. }{ }^{67)}\end{array}$ & $\begin{array}{l}\text { BAL patterns and } \\
\text { clinical pheno- } \\
\text { types }\end{array}$ & $\begin{array}{l}\text { BAL for cell count and differ- } \\
\text { ential, bacterial and viral } \\
\text { studies, spirometry, and } \\
\text { blood test were done. } \\
\text { Outcomes were compared } \\
\text { among } 4 \text { BAL granulocyte } \\
\text { patterns. }\end{array}$ & $\begin{array}{l}\text { Pauci-granulocytic BAL was the most prevalent granulo- } \\
\text { cyte category (52\%), and children with pauci-granulocytic } \\
\text { BAL had less postbronchodilator airflow limitation, less } \\
\text { blood eosinophilia, and less detection of BAL enterovirus. } \\
\text { Children with mixed granulocytic BAL and isolated eo- } \\
\text { sinophilia BAL took more maintenance prednisone, and } \\
\text { had greater blood eosinophilia and allergen sensitization } \\
\text { compared with those with pauci-granulocytic BAL. }\end{array}$ & $\begin{array}{l}\text { In } 32 \% \text { of children evaluated, BAL } \\
\text { revealed corticosteroid-refractory } \\
\text { eosinophilic infiltration amenable } \\
\text { to anti- } \mathrm{TH}_{2} \text { biological therapies, } \\
\text { and in } 12 \% \text {, a treatable bacterial } \\
\text { pathogen. }\end{array}$ \\
\hline $\begin{array}{l}\text { Wang } \\
\text { et al. }^{68)}\end{array}$ & $\begin{array}{l}\text { Predictors of as- } \\
\text { thma remission }\end{array}$ & $\begin{array}{l}2 \text { Remission definitions: a clini- } \\
\text { cal definition/a strict defini- } \\
\text { tion } \\
\text { Both included normal lung func- } \\
\text { tion and the absence of } \\
\text { symptoms, exacerbations, } \\
\text { and medication use. } \\
\text { The strict definition also includ- } \\
\text { ed normal airways respon- }\end{array}$ & $\begin{array}{l}\text { By adulthood, } 26.0 \% \text { of } 879 \text { participants were in clinical } \\
\text { remission, and } 15.0 \% \text { of } 741 \text { participants were in strict } \\
\text { remission. } \\
\text { The degree of } F E V_{1} / F V C \text { ratio impairment and decreased } \\
\text { airways responsiveness were the predictor of asthma } \\
\text { remission. } \\
\text { The combination of normal FEV } 1 / F V C \text { ratio, airways } \\
\text { responsiveness, and serum eosinophil count at base- } \\
\text { line yielded greater than } 80 \% \text { probability of remission }\end{array}$ & $\begin{array}{l}\text { A considerable minority of pati- } \\
\text { ents with persistent childhood } \\
\text { asthma will have disease remis- } \\
\text { sion by adulthood. } \\
\text { Clinical prognostic indicators of } \\
\text { asthma remission, including } \\
\text { baseline lung function, can be } \\
\text { seen from an early age. }\end{array}$ \\
\hline
\end{tabular}
ed normal airways responsiveness.

Kansal Induced sputum 91 Children aged 7-18 years et al. ${ }^{69)}$ eosinophil and with newly diagnosed mild clinical parame- or moderate persistent asters thma

The induced sputum eosino phil percentage was ob tained at the time of enrollment and 3 months after treatment with inhaled budesonide.

line yielded greater than $80 \%$ probability of remission by adulthood.

Sputum eosinophil percentage was high $(3.1 \% \pm 0.515 \%)$
at the time of enrollment which reduced significantly at the time of enrollment which reduced signific 3 months of inhaled budesonide therapy.

Children with moderate persistent asthma had significantly higher values of sputum eosinophil levels than children with mild persistent asthma but the difference was not significant after 3 months of ICS therapy.

A significant negative correlation was found between reduction in sputum eosinophil levels and improvement in FEV 1 .

Guiddir BAL patterns in Children with moderate-toet al. $^{70)}$ steroid-refrac- severe asthma and pretory asthma and school children with modecluster analysis rate-to-severe recurrent wheeze were enrolled.

They underwent standardized clinical and blood workup, and BAL evaluation.

Cluster analysis was applied to 350 children with 34 variables.

Cluster 1, Neutrophilic steroid-refractory recurrent wheeze phenotype, with 138 children uncontrolled despite high-dose ICS, with more history of pneumonia, more gastroesophageal reflux disease, and the highest blood neutrophil counts;

Cluster 2, Severe recurrent wheeze with sensitization to a single aeroallergen, with 104 children controlled with high-dose ICS;

Cluster 3, Eosinophilic steroid-refractory asthma phenotype, with 108 children uncontrolled despite high-dose ICS with more allergic rhinitis, atopic dermatitis, and food allergies.

They also had a higher blood eosinophil count and a higher percentage of BAL eosinophil.

Ullmann Blood eosinophil All patients underwent blood $86 \%$ had normal blood eosinophils, but of these, $84 \%$ et al. ${ }^{71)}$ counts rarely tests, FeNO, sputum inducreflect airway tion, BAL and EB. eosinophilia

had airway eosinophilia.

In children with STRA blood eosinophilia was associated with airway eosinophilia.

However, normal blood eosinophil levels did not exclude airway eosinophilic inflammation.

Eosinophil levels in induced sputum correlate well with clinical asthma parameters and asthma severity in children.

Inflammation pathway of asthma and recurrent wheeze are related to eosinophil cells in older children and neutrophil cells in younger children.

Peripheral blood counts are not reliable in characterizing airway inflammation in severe asthmatic children exposed to high-dose steroid therapy, therefore bronchoscopy with BAL should be considered.

Fleming Use of sputum 55 Children (7-17 years) with et al. ${ }^{38)}$ eosinophil severe asthma were rancounts to guide domized to either a convenmanagement of tional symptom-based asthma management strategy or to an inflammation- based strategy.

The annual rate of exacerbations was nonsignificantly lower in the inflammatory management group compared with the symptom management group.

Significantly fewer subjects in the inflammatory management group experienced an exacerbation within 28 days of a study visit.

There was no significant difference in the ICS dose.

Incorporating the control of sputum eosinophils into the management did not significantly reduce exacerbations or improve asthma control.

Exacerbations were reduced in the short term, suggesting that more frequent measurements would be needed for a clinically useful effect.

$\mathrm{Cl}$, confidence interval; BAL, bronchoalveolar lavage; EB, endobronchial biopsy; FeNO, exhaled nitric oxide; FEV 1 , forced expiratory volume in 1 second; FVC, forced vital capacity; ICS, inhaled corticosteroid; STRA, severe therapy-resistant asthma. 
Table 2. Clinical studies of antieosinophil (anti-IL-5) drugs in children

\begin{tabular}{|c|c|c|c|c|}
\hline Drug (Target) & Type of study & Subjects & Dose \& route & Main Results \\
\hline \multirow[t]{2}{*}{$\begin{array}{l}\text { Mepolizumab } \\
(\text { IL-5) }\end{array}$} & $\begin{array}{l}\text { A randomized double- } \\
\text { blind placebo-con- } \\
\text { trolled trial }^{72)}\end{array}$ & $\begin{array}{l}135 \text { Patients, } 16-74 \text { years old } \\
\text { with severe eosinophilic asth- } \\
\text { ma }\end{array}$ & $\begin{array}{l}\text { Mepolizumab } 100 \mathrm{mg} \\
\text { subcutaneously } \\
\text { every } 4 \text { weeks for } \\
20 \text { weeks }\end{array}$ & $\begin{array}{l}\text { The likelihood of a reduction in the gluco- } \\
\text { corticoid-dose stratum was } 2.39 \text { times } \\
\text { greater in the mepolizumab group } \\
\text { The median percentage reduction from } \\
\text { baseline in the glucocorticoid dose was } 50 \% \\
\text { in the mepolizumab group } \\
\text { Reduced exacerbations, and improved control } \\
\text { of asthma symptoms }\end{array}$ \\
\hline & $\begin{array}{l}\text { A randomized, double- } \\
\text { blind placebo-con- } \\
\text { trolled trial }\end{array}$ & $\begin{array}{l}576 \text { Patients, } 12-82 \text { years old } \\
\text { with uncontrolled eosinophilic } \\
\text { asthma }\end{array}$ & $\begin{array}{l}\text { Two doses of mepol- } \\
\text { izumab ( } 75 \text { mg IV, } \\
100 \text { mg SC injec- } \\
\text { tion) for } 32 \text { weeks } \\
\text { at 4-week intervals }\end{array}$ & $\begin{array}{l}\text { Acute exacerbations were reduced (IV group: } \\
47 \%, \text { SC group: } 53 \% \text { ) compared with the } \\
\text { placebo group. } \\
\text { Acute exacerbations decreased by } 32 \% \text { in the } \\
\text { IV group and } 61 \% \text { in the SC group. } \\
\text { Both the IV and the SC groups had improved } \\
\text { ACQ scores compared with the placebo } \\
\text { group. } \\
\text { FEV } 1 \text { increased in the IV group and in the SC } \\
\text { group compared with the placebo group. }\end{array}$ \\
\hline
\end{tabular}

Open-label, uncontroll- Children aged 6 to 11 years SC mepolizumab of ed, repeat-dose extension study ${ }^{54}$

with severe asthma with blood eosinophil counts $\geq 150$ cells $/ \mathrm{mL}$ at screening or $\geq 300$ cells $/ \mathrm{mL}$ in the previous year

$\begin{array}{cc}\begin{array}{l}\text { Reslizumab } \\ (\text { IL-5) }\end{array} & \begin{array}{l}\text { A randomized, double- } \\ \text { blind placebo-con- } \\ \text { trolled trial }\end{array}\end{array}$

931 Patients, aged 12-75 Reslizumab IV 3 mg/ years with inadequately kgevery 4 weeks controlled asthma with elevated blood eosinophils ( $\geq$ $400 / \mathrm{mL}$ ) stratified by age of asthma onset (early-onset: <40, late-onset: >40 years)

A randomized, double-blind placebocontrolled trial $^{74)}$

315 Patients aged 12 to 75 years with asthma inadequately controlled by at least a medium-dose inhaled corticosteroid and with a blood eosinophil count $\geq 400$ cells $/ \mathrm{mL}$.

A randomized, double-blind placebocontrolled trial ${ }^{60)}$

953 Patients, aged 12-75 years with eosinophilic asthma inadequately controlled

$40 \mathrm{mg}(<40 \mathrm{~kg})$ or $100 \mathrm{mg}(\geq 40 \mathrm{~kg})$ over 52 weeks

Compared to baseline, mepolizumab treatment reduced blood eosinophil counts and asthma exacerbations and improved asthma control.

Reslizumab produced a $75 \%$ relative reduction in asthma exacerbations compared to placebo.

Late-onset asthma ( $\geq 40$ years old) showed higher reduction of asthma exacerbations than early-onset asthma.

Reslizumab 0.3 or Reslizumab significantly improved $\mathrm{FEV}_{1}$ and $3.0 \mathrm{mg} / \mathrm{kg}$ or pla- Clinically meaningful increases in FVC and cebo administered FEF25\%-75\% were observed.

once every 4 weeks Reslizumab improved scores on ACQ and for 16 weeks

AQLQ.

IV reslizumab (3.0 A significant reduction in the frequency of $\mathrm{mg} / \mathrm{kg}$ ) or placebo every 4 weeks for 1 year

An international mul- 1,051 Patients aged 12-77 ticenter, nonrando- years mized, open-label After participation in 1 of 3 extension study ${ }^{62)}$

placebo-controlled, phase III trials patients received reslizumab $3.0 \mathrm{mg} / \mathrm{kg} \mathrm{IV}$ every 4 weeks for up to 24 months.

Resing

Reslizumab 3.0 $\mathrm{mg} / \mathrm{kg}$ IV every 4 weeks for up to 24 months.

asthma exacerbations

Reslizumab-experienced patients maintained improved lung function and asthma control.

Blood eosinophil counts appeared to be returning to baseline after reslizumab discontinuation.

Initial improvements in lung function and asthma control were maintained for up to 2 years.

Benralizumab A randomized, dou- Patients (aged 12-75 years) Randomly assigned (IL-5 receptor) ble-blind, parallelgroup, placebocontrolled phase 3 study ${ }^{63)}$ with at least 2 exacerbations while on high-dosage ICS and long-acting $\beta 2$-agonists in the previous year

A randomized, double-blind, placebocontrolled phase 3 trial $^{64)}$
Patients aged $12-75$ years with severe asthma uncontrolled by medium dosage to high-dosage ICS plus longacting $\beta_{2}$-agonists.
$(1: 1: 1)$ to benralizumab 30 mg either Q4W or Q8W or placebo

Benralizumab reduced the annual asthma exacerbation rate over 48 weeks when given Q4W or Q8W.

Both benralizumab dosing regimens significantly improved prebronchodilator FEV 1 Asthma symptoms were improved by the $\mathrm{Q} 8 \mathrm{~W}$ regimen, but not the $\mathrm{Q} 4 \mathrm{~W}$ regimen.

Patients were ran- Benralizumab resulted in significantly lower domly assigned $(1: 1: 1)$ to receive 56 weeks of benralizumab $30 \mathrm{mg}$ Q4W, benralizumab 30 mg Q8W, or placebo (all SC). annual exacerbation rates with the Q4W regimen and $\mathrm{Q} 8 \mathrm{~W}$ regimen compared with placebo.

Benralizumab also significantly improved pre-bronchodilator FEV1 (Q4W and Q8W) and total asthma symptom score (Q8W only) in these patients.

IL, interleukin; SC, subcutaneous; SGRQ, St George's Respiratory Questionnaire; AEs, adverse events; IV, intravenous; ACQ, Asthma Control Questionnaire; FEV1, forced expiratory volume in 1 second; FVC, forced vital capacity; FEF $25 \%-75 \%$, forced expiratory flow 25\%-75\%; AQLQ, Asthma Quality of Life Questionnaire; ICS, inhaled corticosteroid; SABA, short-acting beta-agonists; Q4W, every 4 weeks; Q8W, every 8 weeks. 


\section{Reslizumab}

Reslizumab (Cinqair; Teva Respiratory, Frazer, PA, USA) is an IgG4 humanized monoclonal antibody against IL-5 that has been approved by the FDA as a treatment for severe EA in patients 18 years of age or older. Reslizumab is generally recommended to be administered at a dose of $3 \mathrm{mg} / \mathrm{kg}$ intravenously every 4 weeks. ${ }^{55}$ ) In a phase 3 study of reslizumab, improvements in lung function did not differ from the placebo group when the blood eosinophil count was less than 400 cells $/ \mathrm{mL}^{56}$ Mukherjee et al. ${ }^{57)}$ found that fixed-dose mepolizumab did not significantly affect steroiddependent asthma, whereas weight-based reslizumab treatment had superior ability to reduce sputum eosinophils and improve asthma control compared with placebo. In a study by Castro et al., ${ }^{58)}$ serum and sputum eosinophils decreased and $\mathrm{FEV}_{1}$ improved in the group administered reslizumab $3 \mathrm{mg} /$ $\mathrm{kg}$ for 15 weeks compared with the placebo group. There was no significant intergroup difference in ACQ score, but among patients with a nasal polyp, the reslizumab group had a higher ACQ score than the placebo group. Although large-scale studies on the effect of reslizumab on steroid dose reduction in asthma patients who have been using oral steroids long term are lacking, reslizumab effectively improved asthma control and lung function in prednisone-dependent patients. ${ }^{59)}$ Another study reported a significant decrease in the frequency of asthma exacerbations in patients receiving reslizumab versus the placebo group. ${ }^{60)}$

In one study that included children aged 12 years or older with elevated blood eosinophils $(\geq 400 / \mathrm{mL})$ and inadequately controlled asthma, reslizumab produced a $75 \%$ relative reduction in asthma exacerbations compared to placebo. However, late-onset asthma ( $\geq 40$ years old) showed a higher reduction in asthma exacerbations than early-onset asthma $(<40$ years old). ${ }^{61)}$

In a phase 3 trial of patients with moderate-to-severe EA (blood eosinophils $\geq 400 / \mathrm{mL}$ ) who were aged 12 years or older, reslizumab $3 \mathrm{mg} / \mathrm{kg}$ was injected intravenously every 4 weeks for up to 24 months. Reslizumab showed favorable long-term safety, and the initial improvements in $\mathrm{FEV}_{1}$, forced vital capacity, and forced expiratory flow at $25 \%-75 \%$ of the pulmonary volume were maintained for up to 2 years. ${ }^{62}$

\section{Benralizumab}

Benralizumab (Fasenra; AstraZeneca, Cambridge, UK), a humanized IgG1 monoclonal antibody that binds to the IL-5 receptor $\alpha$ subunit of eosinophils and basophils, has been approved by the FDA for further treatment in patients with severe EA aged 12 years or older. When the antibody is bound, it causes cellular apoptosis through cell-mediated cytotoxicity. The 3 main placebo-controlled studies of benralizumab in patients with severe uncontrolled EA are the SIROCCO, CALIMA, and
ZONDA trials.

In the SIROCCO trial, 1,205 patients were administered benralizumab or placebo for 48 weeks. The study included children aged 12 years or older as well as adults. Asthma exacerbations were reduced and $\mathrm{FEV}_{1}$ was improved in the benralizumab-administered group versus the control group. ${ }^{63}$ The CALIMA trial included 1,306 patients over 56 weeks. Similarly, asthma exacerbation was reduced and FEV1 was improved in the benralizumab-treated group. ${ }^{64)}$ In the ZONDA trial, 220 subjects were enrolled for 28 weeks. Oral corticosteroid needs were reduced by $75 \%$ in the benralizumab-treated group and by $25 \%$ in the placebo group $(P<0.001)$. Asthma exacerbations were also significantly reduced in the benralizumab-treated group. ${ }^{65)}$

\section{Conclusion}

Eosinophils are important in the pathogenesis of asthma and useful for evaluating asthma. With the recent introduction of anti-IL-5 agents that suppress eosinophils, the scope of asthma treatment has been broadened, and these medications are helpful for patients with severe EA. Although the role of eosinophils in asthma has been investigated in many studies, further studies are needed to deepen our understanding of asthma.

\section{Conflicts of interest}

No potential conflict of interest relevant to this article was reported.

\section{References}

1. Wurth M, Papantonakis CM, Nevel RJ, Thomas CS, Sokolow AG, Moore PE, et al. Risk factors associated with asthma development and control in children. Mouse infestation, antipyretics, respiratory viruses, and allergic sensitization. Am J Resp Crit Care Med 2017;196:1605.

2. Masoli M, Fabian D, Holt S, Beasley R; Global Initiative for Asthma (GINA) Program. The global burden of asthma: executive summary of the GINA Dissemination Committee report. Allergy 2004;59:469-78.

3. Kim BK, Kim JY, Kang MK, Yang MS, Park HW, Min KU, et al. Allergies are still on the rise? A 6-year nationwide population-based study in Korea. Allergol Int 2016;65:186-91.

4. Wenzel SE. Asthma: defining of the persistent adult phenotypes. Lancet 2006;368:804-13.

5. Robinson DS, Hamid Q, Ying S, Tsicopoulos A, Barkans J, Bentley AM, et al. Predominant TH2-like bronchoalveolar T-lymphocyte population in atopic asthma. NEngl J Med 1992;326:298-304.

6. Woodruff PG, Modrek B, Choy DF, Jia G, Abbas AR, Ellwanger A, et al. T-helper type 2-driven inflammation defines major subphenotypes of asthma. Am J Resp Crit Care Med 2009;180:388-95.

7. Bousquet J, Chanez P, Lacoste JY, Barnéon G, Ghavanian N, Enander I, et al. Eosinophilic inflammation in asthma. N Engl J Med 1990;323:10339.

8. Holgate ST. The epidemic of allergy and asthma. Nature 1999;402:B2-4.

9. Hogan SP, Rosenberg HF, Moqbel R, Phipps S, Foster PS, Lacy P, et al. Eosinophils: biological properties and role in health and disease. Clin Exp Allergy 2008;38:709-50.

10. Trivedi S, Lloyd C. Eosinophils in the pathogenesis of allergic airways 
disease. Cell Mol Life Sci 2007;64:1269.

11. Ying S, Meng Q, Zeibecoglou K, Robinson DS, Macfarlane A, Humbert $\mathrm{M}$, et al. Eosinophil chemotactic chemokines (eotaxin, eotaxin-2, RANTES, monocyte chemoattractant protein-3 (MCP-3), and MCP4), and CC chemokine receptor 3 expression in bronchial biopsies from atopic and nonatopic (Intrinsic) asthmatics. J Immunol 1999;163:63219.

12. Uhm TG, Kim BS, Chung IY. Eosinophil development, regulation of eosinophil-specific genes, and role of eosinophils in the pathogenesis of asthma. Allergy Asthma Immunol Res 2012;4:68-79.

13. Young B, Woodford P, O'Dowd G. Wheater's functional histology E-Book: a text and colour atlas. 6th ed. Philadelphia (PA): Elsevier Health Sciences, 2013.

14. Blanchard C, Rothenberg ME. Biology of the eosinophil. Adv Immunol 2009;101:81-121.

15. Rothenberg ME. Eosinophilia. N Engl J Med 1998;338:1592-600.

16. Carr TF, Zeki AA, Kraft M. Eosinophilic and noneosinophilic asthma. Am J Resp Crit Care Med 2018;197:22-37.

17. Arron JR, Choy DF, Scheerens H, Matthews JG. Noninvasive biomarkers that predict treatment benefit from biologic therapies in asthma. Ann Am Thorac Soc 2013;10:S206-13.

18. Hargreave FE. Induced sputum and response to glucocorticoids. J Allergy Clin Immunol 1998;102:S102-5.

19. Szefler SJ, Martin RJ, King TS, Boushey HA, Cherniack RM, Chinchilli $\mathrm{VM}$, et al. Significant variability in response to inhaled corticosteroids for persistent asthma. J Allergy Clin Immunol 2002;109:410-8.

20. Fitzpatrick AM, Teague WG, Meyers DA, Peters SP, Li X, Li H, et al. Heterogeneity of severe asthma in childhood: confirmation by cluster analysis of children in the National Institutes of Health/National Heart, Lung, and Blood Institute Severe Asthma Research Program. J Allergy Clin Immunol 2011;127:382-9. e13.

21. Loza M. ADEPT and U-BIOPRED investigators. Longitudinally stable, clinically defined clusters of patient with asthma independently identified in the ADEPT and U-BIOPRED asthma studies. Ann Am Thorac Soc 2016;13:S102-3.

22. Burks AW, Holgate ST, O'Hehir RE, Bacharier LB, Broide DH, Hershey GKK, et al. Middleton's allergy E-Book: principles and practice. Philadelphia (PA): Elsevier Health Sciences, 2019.

23. Gleich G, Adolphson C. The eosinophil and bronchial asthma: evidence for a critical role of eosinophils in pathophysiology. Lung Biol Health Dis 1999;125:1-37.

24. Walsh ER, August A. Eosinophils and allergic airway disease: there is more to the story. Trends Immunol 2010;31:39-44.

25. Wang H-B, Ghiran I, Matthaei K, Weller PF. Airway eosinophils: allergic inflammation recruited professional antigen-presenting cells. J Immunol 2007;179:7585-92.

26. Duez C, Dakhama A, Tomkinson A, Marquillies P, Balhorn A, Tonnel $\mathrm{AB}$, et al. Migration and accumulation of eosinophils toward regional lymph nodes after airway allergen challenge. J Allergy Clin Immunol 2004;114:820-5.

27. Brusselle GG, Maes T, Bracke KR. Eosinophils in the spotlight: eosinophilic airway inflammation in nonallergic asthma. Nature med 2013;19:977-9.

28. Smith SG, Chen R, Kjarsgaard M, Huang C, Oliveria JP, O'Byrne PM, et al. Increased numbers of activated group 2 innate lymphoid cells in the airways of patients with severe asthma and persistent airway eosinophilia. J Allergy Clin Immunol 2016;137:75-86. e8.

29. Hernnäs J, Särnstrand B, Lindroth P, Peterson C, Venge P, Malmström A. Eosinophil cationic protein alters proteoglycan metabolism in human lung fibroblast cultures. Eur J Cell Biol 1992;59:352-63.

30. Zagai U, Dadfar E, Lundahl J, Venge P, Sköld CM. Eosinophil cationic protein stimulates TGF- $\beta 1$ release by human lung fibroblasts in vitro. Inflammation 2007;30:153-60.

31. Zagai U, Sköld C, Trulson A, Venge P, Lundahl J. The effect of eosinophils on collagen gel contraction and implications for tissue remodelling. Clin Exp Allergy Immunol 2004;135:427-33.

32. Pégorier S, Wagner LA, Gleich GJ, Pretolani M. Eosinophil-derived cationic proteins activate the synthesis of remodeling factors by airway epithelial cells. J Immunol 2006;177:4861-9.

33. Flood-Page P, Menzies-Gow A, Phipps S, Ying S, Wangoo A, Ludwig MS, et al. Anti-IL-5 treatment reduces deposition of ECM proteins in the bronchial subepithelial basement membrane of mild atopic asthmatics. J Clin Invest 2003;112:1029-36.

34. Wenzel SE, Schwartz LB, Langmack EL, Halliday JL, Trudeau JB, Gibbs RL, et al. Evidence that severe asthma can be divided pathologically into two inflammatory subtypes with distinct physiologic and clinical characteristics. Am J Resp Crit Care Med 1999;160:1001-8.

35. De Gouw H, Smits H, Sont J, Hiemstra P, Sterk P, Bel E. Repeatability of cellular and soluble markers of inflammation in induced sputum from patients with asthma. Eur Respir J 1996;9:2441-7.

36. Szefler SJ, Wenzel S, Brown R, Erzurum SC, Fahy JV, Hamilton RG, et al. Asthma outcomes: biomarkers. J Allergy Clin Immunol 2012;129(3 Suppl):S9-23.

37. Jayaram L, Pizzichini M, Cook R, Boulet L, Lemiere C, Pizzichini E, et al. Determining asthma treatment by monitoring sputum cell counts: effect on exacerbations. Eur Respir J 2006;27:483-94.

38. Fleming L, Wilson N, Regamey N, Bush A. Use of sputum eosinophil counts to guide management in children with severe asthma. Thorax 2012;67:193-8.

39. Berry A, Busse WW. Biomarkers in asthmatic patients: has their time come to direct treatment? J Allergy Clin Immunol 2016;137:1317-24.

40. Hastie AT, Moore WC, Li H, Rector BM, Ortega VE, Pascual RM, et al. Biomarker surrogates do not accurately predict sputum eosinophil and neutrophil percentages in asthmatic subjects. J Allergy Clin Immunol 2013;132:72-80. e12.

41. Dweik RA, Boggs PB, Erzurum SC, Irvin CG, Leigh MW, Lundberg JO, et al. An official ATS clinical practice guideline: interpretation of exhaled nitric oxide levels (FENO) for clinical applications. Am J Resp Crit Care Med 2011;184:602-15.

42. Korevaar DA, Westerhof GA, Wang J, Cohen JF, Spijker R, Sterk PJ, et al. Diagnostic accuracy of minimally invasive markers for detection of airway eosinophilia in asthma: a systematic review and meta-analysis. Lancet Respir Med 2015;3:290-300.

43. Berry M, Shaw D, Green R, Brightling C, Wardlaw A, Pavord I. The use of exhaled nitric oxide concentration to identify eosinophilic airway inflammation: an observational study in adults with asthma. Clin Exp Allergy 2005;35:1175-9.

44. Mummadi SR, Hahn PY. Update on exhaled nitric oxide in clinical practice. Chest 2016;149:1340-4.

45. Jia G, Erickson RW, Choy DF, Mosesova S, Wu LC, Solberg OD, et al. Periostin is a systemic biomarker of eosinophilic airway inflammation in asthmatic patients. J Allergy Clin Immunol 2012;130:647-54. e10.

46. Simpson JL, Yang IA, Upham JW, Reynolds PN, Hodge S, James AL, et al. Periostin levels and eosinophilic inflammation in poorly-controlled asthma. BMC Pulm Med 2016;16:67.

47. Woodruff PG, Boushey HA, Dolganov GM, Barker CS, Yang YH, Donnelly S, et al. Genome-wide profiling identifies epithelial cell genes associated with asthma and with treatment response to corticosteroids. Proc Natl Acad Sci US A 2007;104:15858-63.

48. Wagener AH, de Nijs SB, Lutter R, Sousa AR, Weersink EJ, Bel EH, et al. External validation of blood eosinophils, FENO and serum periostin as surrogates for sputum eosinophils in asthma. Thorax 2015;70:115-20.

49. Takatsu K, Nakajima H. IL-5 and eosinophilia. Curr Opin Immunol 2008;20:288-94.

50. Shardonofsky FR, Venzor III J, Barrios R, Leong KP, Huston DP. Therapeutic efficacy of an anti-IL-5 monoclonal antibody delivered into the respiratory tract in a murine model of asthma. J Allergy Clin Immunol 1999;104:215-21.

51. Nair P, Pizzichini MM, Kjarsgaard M, Inman MD, Efthimiadis A, Pizzichini E, et al. Mepolizumab for prednisone-dependent asthma with sputum eosinophilia. NEngl J Med 2009;360:985-93.

52. Haldar P, Brightling CE, Hargadon B, Gupta S, Monteiro W, Sousa A, et al. Mepolizumab and exacerbations of refractory eosinophilic asthma. N Engl J Med 2009;360:973-84. 
53. Ortega HG, Liu MC, Pavord ID, Brusselle GG, FitzGerald JM, Chetta A, et al. Mepolizumab treatment in patients with severe eosinophilic asthma. NEngl J Med 2014;371:1198-207.

54. Gupta A, Ikeda M, Geng B, Azmi J, Price RG, Bradford ES, et al. Longterm safety and pharmacodynamics of mepolizumab in children with severe asthma with an eosinophilic phenotype. J Allergy Clin Immunol 2019;144:1336-42.

55. Varricchi G, Senna G, Loffredo S, Bagnasco D, Ferrando M, Canonica GW. Reslizumab and eosinophilic asthma: one step closer to precision medicine? Front Immunol 2017;8:242.

56. Corren J, Weinstein S, Janka L, Zangrilli J, Garin M. Phase 3 study of reslizumab in patients with poorly controlled asthma: effects across a broad range of eosinophil counts. Chest 2016;150:799-810.

57. Mukherjee M, Aleman Paramo F, Kjarsgaard M, Salter B, Nair G, LaVigne $\mathrm{N}$, et al. Weight-adjusted intravenous reslizumab in severe asthma with inadequate response to fixed-dose subcutaneous mepolizumab. Am J Resp Crit Care Med 2018;197:38-46.

58. Castro M, Mathur S, Hargreave F, Boulet LP, Xie F, Young J, et al. Reslizumab for poorly controlled, eosinophilic asthma: a randomized, placebo-controlled study. Am J Resp Crit Care Med 2011;184:1125-32.

59. Nair P, Bardin P, Humbert M, Murphy KR, Hickey L, Garin M, et al. Efficacy of intravenous reslizumab in oral corticosteroid-dependent asthma. J Allergy Clin Immunol Pract 2020;8:555-64.

60. Castro M, Zangrilli J, Wechsler ME, Bateman ED, Brusselle GG, Bardin $\mathrm{P}$, et al. Reslizumab for inadequately controlled asthma with elevated blood eosinophil counts: results from two multicentre, parallel, doubleblind, randomised, placebo-controlled, phase 3 trials. Lancet Respir Med 2015;3:355-66.

61. Brusselle G, Germinaro M, Weiss S, Zangrilli J. Reslizumab in patients with inadequately controlled late-onset asthma and elevated blood eosinophils. Pulm Pharmacol Ther 2017;43:39-45.

62. Murphy K, Jacobs J, Bjermer L, Fahrenholz JM, Shalit Y, Garin M, et al. Long-term safety and efficacy of reslizumab in patients with eosinophilic asthma. J Allegy Clin Immunol Pract 2017;5:1572-81.e3.

63. Bleecker ER, FitzGerald JM, Chanez P, Papi A, Weinstein SF, Barker P, et al. Efficacy and safety of benralizumab for patients with severe asthma uncontrolled with high-dosage inhaled corticosteroids and long-acting $\beta 2$-agonists (SIROCCO): a randomised, multicentre, placebo-controlled phase 3 trial. Lancet 2016;388:2115-27.

64. FitzGerald JM, Bleecker ER, Nair P, Korn S, Ohta K, Lommatzsch M, et al. Benralizumab, an anti-interleukin-5 receptor $\alpha$ monoclonal antibody, as add-on treatment for patients with severe, uncontrolled, eosinophilic asthma (CALIMA): a randomised, double-blind, placebo-controlled phase 3 trial. Lancet 2016;388:2128-41.

65. Nair P, Wenzel S, Rabe KF, Bourdin A, Lugogo NL, Kuna P, et al. Oral glucocorticoid-sparing effect of benralizumab in severe asthma. N Engl J Med 2017;376:2448-58.

66. Ross KR, Gupta R, DeBoer MD, Zein J, Phillips BR, Mauger DT, et al. Severe asthma during childhood and adolescence: A longitudinal study. J Allergy 2020;145:140-6.e9.

67. Teague WG. Blood eosinophilia may not adequately estimate lung fluid eosinophilia in childhood asthma. J Allergy Clin Immunol Pract 2019; 7:2497-8.

68. Wang AL, Datta S, Weiss ST, Tantisira KG. Remission of persistent childhood asthma: Early predictors of adult outcomes. J Allergy Clin Immunol 2019; 143:1752-9.e6.

69. Kansal P, Nandan D, Agarwal S, Patharia N, Arya N. Correlation of induced sputum eosinophil levels with clinical parameters in mild and moderate persistent asthma in children aged 7-18 years. J asthma 2018; 55:385-90.

70. Guiddir T, Saint-Pierre P, Purenne-Denis E, Lambert N, Laoudi Y, Couderc R, et al. Neutrophilic steroid-refractory recurrent wheeze and eosinophilic steroid-refractory asthma in children. J Allergy Clin Immunol Pract 2017;5:1351-61.e2.

71. Ullmann N, Bossley C, Fleming L, Silvestri M, Bush A, Saglani S. Blood eosinophil counts rarely reflect airway eosinophilia in children with severe asthma. Allergy 2013;68:402-6.

72. Bel EH, Wenzel SE, Thompson PJ, Prazma CM, Keene ON, Yancey SW, et al. Oral glucocorticoid-sparing effect of mepolizumab in eosinophilic asthma. New Engl J Med 2014;371:1189-97.

73. Brusselle G, Germinaro M, Weiss S, Zangrilli J. Reslizumab in patients with inadequately controlled late-onset asthma and elevated blood eosinophils. Pul Pharmacol 2017;43:39-45.

74. Bjermer L, Lemiere C, Maspero J, Weiss S, Zangrilli J, Germinaro M. Reslizumab for inadequately controlled asthma with elevated blood eosinophil levels: a randomized phase 3 study. Chest 2016;150:789-98.

How to cite this article: Choi BS. Eosinophils and childhood asthma. Clin Exp Pediatr 2021;64:60-7. https://doi.org/10.3345/ cep.2020.00717 